\title{
PENGARUH PENAMBAHAN ANGGUR LAUT (Caulerpa racemosa) SEBAGAI SUMBER ANTIOKSIDAN TERHADAP NILAI SENSORI DAN NILAI PROKSIMAT PADA PRODUK DODOL
}

\author{
Yana Meutia Yunus Date*, Asnani, Moh. Nuh Ibrahim \\ Jurusan Teknologi Hasil Perikanan Fakultas Perikanan dan Ilmu Kelautan Universitas Halu Oleo, Jalan \\ H.E.A Mokodompit Kampus Bumi Tridharma Anduonohu, Kendari 93232 Sulawesi Tenggara \\ Telepon +6282188916185 \\ *Korespondensi: yanameutia09@gmail.com \\ Diterima: 19 Maret 2019/Disetujui: 10 April 2019
}

Cara sitasi: Date YMY, Asnani, Ibrahim MN. 2019. Pengaruh penambahan anggur laut (Caulerpa racemosa) sebagai sumber antioksidan terhadap nilai sensori dan nilai proksimat pada produk dodol. Jurnal Fish Protech. 2(1):78-88.

\begin{abstract}
Abstrak
Penelitian ini bertujuan untuk mengetahui pengaruh perbandingan jumlah anggur laut dan tepung beras ketan yang digunakan terhadap nilai sensori, komposisi proksimat, dan aktivitas antioksidan dodol anggur laut. Penelitian ini menggunakan variasi konsentrasi anggur laut dan tepung beras ketan berturut-turut A (AL 40 : TK 60\%), B (AL 20 : TK 80\%), C (AL 0 : TK100\%). Analisis uji sensori, komposisi proksimat dan aktivitas antioksidan (metode DPPH). Nilai sensori berturut-turut tertinggi (kenampakan, aroma, tekstur dan rasa) terdapat pada perlakuan A dengan nilai 4,20, 4,10, 4,40, dan 4,20. Nilai komposisi proksimat berturut-turut tertinggi (kadar air, kadar abu, kadar lemak, kadar protein dan kadar karbohidrat) terdapat pada perlakuan A dengan nilai 36,12, $0,25,12,41,16,61$, dan 50,35\%. Nilaiaktivitas antioksidan tertinggi terdapat pada perlakuan A dengan nilai $619,206 \mu \mathrm{g} / \mathrm{mL}$. Dari statistik uji beda nyata (DMRT) menunjukkan bahwa terdapat perbedaan nyata pada kenampakan, tekstur, rasa, kadar air, kadar protein, dan kadar karbohidrat pada dodol anggur laut.
\end{abstract}

Kata kunci : Anggur laut, tepung beras ketan, dodol, uji sensori, aktivitas antioksidan

\section{THE EFFECT OF ADDING Caulerpa racemosa AS A SOURCE OF ANTIOXIDANTS TO SENSORY VALUES AND THE PROXIMATE VALUES OF DODOL PRODUCTS}

\begin{abstract}
This aims to determine the effect of the ratio of the amount of Caulerpa racemosa and sticky rice flour used to sensory values, proximate composition, and antioxidant activity of Caulerpa racemosa dodol. This study used variations in the concentration of Caulerpa racemosaand sticky rice flour in successive A (AL 40: TK 60\%), B (AL 20: TK $80 \%$ ), C (AL 0: TK 100\%). Analysis of sensory test, proximate composition and antioxidant activity (DPPH method). The highest sensory values (appearance, odour, texture and taste) were found in treatment $\mathrm{A}$ with values of 4,20, 4,10, 4.40, and 4,20. The highest proximate composition test results (moisture content, ash content, fat content, protein content and carbohydrate content) were found in treatment A with
\end{abstract}


values of $36,12,0,25,12,41,16,61$, and $50,35 \%$. The highest test results of antioxidant activity were found in treatment A with a value of $619,206 \mu \mathrm{g} / \mathrm{mL}$. From the real difference test statistics (DMRT) shows that there are significant differences in appearance, texture, taste, moisture content, protein content, and carbohydrate content in Caulerpa racemosa dodol.

Key words: Caulerpa racemosa, sticky rice flour, dodol, sensory test, antioxidant activity.

\section{PENDAHULUAN}

Caulerpa racemosa merupakan salah satu jenis dari rumput laut yang keberadaannya melimpah di Sulawesi Tenggara, salah satunya di desa Tanjung Tiram, Kecamatan Moramo, Konawe Selatan. Anggur laut memiliki fungsi ekonomis yaitu dapat dimanfaatkan sebagai bahan makanan karena memiliki kandungan gizi yang cukup tinggi sebagai sumber protein nabati, mineral, maupun vitamin (Verlaque et al., 2003).

Berbagai penelitian telah membuktikan bahwa $C$ racemosa mengandung asam folat, tiamin, asam askorbat (Chew et al., 2008), dan fenol (Chew et al., 2007) sebagai hasil metabolit sekunder yang berfungsi sebagai antioksidan. Keberadaan senyawa tersebut menjadikan C. racemosa bernilai ekonomis tinggi karena selain dimanfaatkan sebagai bahan makanan, dapat dimanfaatkan sebagai bahan pangan fungsional dan obat (Anwar et al., 2016). Hasil analisis komposisi kimia dari $C$. racemosa menunjukkan bahwa anggur laut memiliki kadar air yang cukup tinggi sehingga mudah mengalami kerusakan (Turangan, 2000). Oleh karena itu diversifikasi pengolahan anggur laut sangat dibutuhkan untuk mengoptimalkan pengolahan anggur laut dan pemanfaatannya sehingga menjadi suatu produk yang bergizi, bersifat fungsional serta memberi nilai tambah penghasilan bagi masyarakat. Salah satu produk yang memiliki nilai tambah dan mudah untuk dibuat yaitu dodol.

Dodol merupakan suatu olahan pangan yang dibuat dari campuran tepung beras ketan, gula merah, santan kelapa yang dididihkan hingga menjadi kental dan berminyak tidak lengket, dan apabila dingin pasta akan menjadi padat, kenyal dan dapat diiris. Jenis dodol sangat beragam tergantung keragaman campuran tambahan dan juga cara pembuatannya (Haryadi, 2006). Dodol mempunyai tekstur lunak, mempunyai sifat elastis, dapat langsung dimakan, tidak memerlukan pendinginan dan juga cukup kering sehingga dapat stabil selama penyimpanan (Astawan dan Wahyuni, 1991). Agar produk yang dihasilkan dapat bertahan lama, dalam pembuatan dodol salah satu bahan tambahan utama yang digunakan yaitu tepung beras ketan.

Tepung beras ketan (Oryza sativa glutinosa) merupakan tepung yang terbuat dari beras ketan putih, dengan cara digiling atau ditumbuk. Beras ketan mengandung zat pati (sekitar 80-85\%), vitamin (terutama pada bagian aleuron), mineral dan air. Komposisi kimiawi beras ketan putih terdiri dari karbohidrat 79,4\%; protein $6,7 \%$; lemak $0,7 \%$ dan air $12 \%$ (Triwitono, 2012). Kadar amilopektin yang tinggi menyebabkan tepung beras ketan putih sangat mudah mengalami 
gelatinisasi bila ditambahkan dengan air dan memperoleh perlakuan pemanasan. Hal ini terjadi karena adanya pengikatan hidrogen dan molekul-molekul tepung beras ketan ( $\mathrm{gel}$ ) bersifat kental (Suprapto, 2006). Oleh karena itu tepung beras ketan dapat digunakan sebagai bahan dalam pembuatan dodol.Salah satu produk olahan anggur laut yang dilakukan adalah dodol anggur laut. Adapun tujuan dari peneitian ini adalah untuk mengetahui perbandingan jumlah anggur laut dan tepung beras ketan terhadap nilai sensori, nilai proksimat, dan aktivitas antioksidan dodol anggur laut.

\section{BAHAN DAN METODE}

\section{Bahan dan Alat}

Bahan yang digunakan terdiri atas bahan utama dan bahan pendukung. Bahan utama adalah anggur laut (C. racemosa) segar yang diperoleh dari Desa Tanjung Tiram Kabupaten Konawe Selatan, Sulawesi Tenggara. Bahan pendukung adalah santan kelapa, tepung beras ketan, gula merah, dan garam. Untuk komposisi proksimat dan aktivitas antioksidan adalah aquades, reagen biuret, larutan standar protein, alkohol 80\%, heksan, bovin serum albumin, $\mathrm{NaOH}$, dietil eter, $\mathrm{Na}_{2} \mathrm{SO}_{4}$, $\mathrm{CuSO}_{4}, \mathrm{H}_{2} \mathrm{SO}_{4}$ pekat, dan $\mathrm{HCl}$, metanol, dan larutan DPPH.

Alat yang digunakan dalam penelitian ini ada 2 macam yaitu alat untuk pengolahan dan alat untuk analisis. Alat pengolahan meliputi: baskom, timbangan analitik (M5-ION), pisau, penggiling daging, wadah, wajan, kompor dan stopwatch. Alat untuk analisis proksimat dan analisis antioksidan meliputi: oven, cawan (Normax), penjepit, sudip, timbangan analitik (M5-ION), gunting dan desikator (Equipment Pharmacy), labu lemak, sokhlet (Iwaki), gelas piala (iwaki pyrex), gelas ukur (pyrex), batang pengaduk, pipet tetes (supertek), pipet mikro (topette-nesco), corong (pyrex), sentrifus (KORL-KLOP), tabung reaksi (Pyrex), labu takar (pyrex), Erlenmeyer (pyrex), kondensor (isolab), labu kjedhal (pyrex), tanur (naberthem germany), dan cawan porselin (RRC), cawan aluminium (pyrex), botol semprot (pudak), evaporator $\quad(I K A \AA), \quad$ dan spektofotometerUV-Vis (AMTAST).

\section{Pembuatan Dodol Anggur Laut}

Dodol anggur laut dibuat dengan cara menimbang bahan-bahan yang diperlukan sesuai dengan formula. Bahan utama adalah anggur laut dan tepung beras ketan dengan total berat 200 gr. Adapun pelarut yang digunakan adalah perbandingan anggur laut dan tepung beras ketan berturut-turut $\mathrm{A}$ (AL 40: TK 60\%), B (AL 20 : TK $80 \%$ ), C (AL 0 : TK 100\%). Pertamatama santan kelapa $(500 \mathrm{ml})$ diaduk sampai agak berminyak, kemudian dimasukkan gula merah (100 gram) diaduk sampai mengental, kemudian dimasukkan tepung beras ketan dan anggur laut, kemudian masukkan garam (1 gram). Selanjutnya dilakukan pengadukan diatas api kompor yang sedang selama 25 menit sampai adonan dodol penampakannya mengkilap. Dodol anggur laut didiamkan selama 24 jam pada suhu ruang (Modifikasi metode Hasim et al. 2017).

\section{Penilaian Sensori}

Penilaian sensori terhadap produk dodol anggur yang meliputi kenampakan, aroma, tekstur, dan rasa dengan menggunakan format pengujian sensori. Pengujian ini menggunakan 20 orang panelis (Setyaningsihet al., 2010).

\section{Uji Proksimat Dodol Anggur Laut}

Uji proksimat dodol anggur laut meliputi analisis kadar air, analisis 
kadar abu, analisis kadar lemak, analisis kadar protein, dan analisis kadar karbohidrat (AOAC, 2005).

\section{Uji Aktivitas Antioksidan}

Uji aktivitas antioksidan terhadap produk dodol anggur laut denganmengekstrak metanol dengan dodol anggur laut menggunakan metode DPPH (1,1-diphenyl-2-picrylhydrazil) (Tristantini et al., 2016).

\section{Rancangan Penelitian}

Penelitian ini menggunakan Rancangan Acak Lengkap (RAL) yang terdiri dari 3 perlakuan yaitu A (Anggur Laut 40 : Tepung Beras Ketan 60\%), B (Anggur Laut 20 : Tepung Beras Ketan 80\%), C (Anggur Laut 0 : Tepung Beras Ketan 100\%), diulang sebanyak 3 kali sehingga diperoleh 9 unit percobaan (Sudjana, 2000).

\section{Analisis Data}

Data dianalisis dengan menggunakan sidik ragam Analysis of Variance (ANOVA), jika terdapat pengaruh nyata terhadap variabel pengamatan, maka dilanjutkan dengan uji Duncan's Multiple Range Test (DMRT) pada taraf kepercayaan 95\% $(\alpha=0,05)$ untuk menentukan tiap-tiap perlakuan (Steel and Storrie, 1993).

\section{HASIL DAN PEMBAHASAN}

Hasil analisis ragam produk dodol anggur laut terhadap penilaian uji sensori yang meliputi kenampakan, aroma, tekstur, dan rasa disajikan pada Tabel 1.

Tabel 1. Hasil analisis ragam dari uji sensori, uji proksimat, dan uji aktivitas antioksidan dodol anggur laut

\begin{tabular}{lccc}
\hline \multirow{2}{*}{ Parameter } & \multicolumn{3}{c}{ Perlakuan } \\
\cline { 2 - 4 } & & $\mathrm{B}$ & $\mathrm{C}$ \\
\hline Nilai Sensori & & & \\
Kenampakan $^{1)}$ & $4,20 \pm 0,45^{\mathrm{a}}$ & $3,83 \pm 0,35^{\mathrm{ab}}$ & $3,43 \pm 0,15^{\mathrm{c}}$ \\
Aroma $^{2)}$ & $4,10 \pm 0,1$ & $3,96 \pm 0,2$ & $3,70 \pm 0,1$ \\
Tekstur $^{3)}$ & $4,40 \pm 0,1^{\mathrm{a}}$ & $4,10 \pm 0,1^{\mathrm{b}}$ & $3,90 \pm 0,1^{\mathrm{c}}$ \\
Rasa $^{4)}$ & $4,20 \pm 0,1^{\mathrm{a}}$ & $3,86 \pm 0,2 \mathrm{a}^{\mathrm{b}}$ & $3,70 \pm 0,1^{\mathrm{c}}$ \\
\hline Nilai Proksimat & & & \\
Kadar Air & $36,12 \pm 2,67^{\mathrm{a}}$ & $26,21 \pm 3,50^{\mathrm{ab}}$ & $23,88 \pm 1,01^{\mathrm{c}}$ \\
Kadar Abu $_{\text {Kadar Lemak }}$ & $0,25 \pm 0,01$ & $0,25 \pm 0,01$ & $0,23 \pm 0,02$ \\
Kadar Protein & $12,41 \pm 0,77$ & $11,30 \pm 0,22$ & $10,79 \pm 0,32$ \\
Kadar Karbohidrat & $50,35 \pm 0,49^{\mathrm{a}}$ & $14,89 \pm 0,35^{\mathrm{b}}$ & $13,18 \pm 0,39^{\mathrm{c}}$ \\
\hline Aktivitas & $47,83 \pm 3,63^{\mathrm{b}}$ & $34,57 \pm 2,62^{\mathrm{bc}}$ \\
Antioksidan & $619,206 \pm 456,82$ & $815,665 \pm 341,48$ & $853,029 \pm 221,58$ \\
\hline Kend
\end{tabular}

Keterangan : Notasi yang sama menunjukkan perbedaan tidak nyata pada taraf kepercayaan $95 \%$

1) 5 = Utuh, mengkilap, tidak berampas, rapi, khas dodol, $4=$ Utuh, kurang mengkilap, berampas, rapi, khas dodol, 3 = Utuh, kurang mengkilap, tidak berampas, kurang rapi, khas dodol, 2 = Kurang utuh, kurang mengkilap, tidak berampas, kurang rapi, khas dodol berkurang, 1 = Tidak utuh, tidak mengkilap, berampas, tidak rapi, tidak khas dodol. 2) 5= Tidak ada bau anggur laut, spesifik dodol, tanpa bau tambahan, $4=$ Tidak ada bau anggur laut, spesifik dodol, sedikit bau tamabahan, 3 = Sedikit bau anggur laut, spesifik dodol berkurang, ada bau tambahan, 2 = Bau anggur laut, spesifik dodol berkurang, ada bau tambahan, 1 = Bau anggur laut, tidak ada bau spesifik dodol, dominan bau tambahan. 3) $5=$ Sangat kering, legit, halus (lembut), 4 = Kering, legit, halus (lembut), $3=$ Kurang kering, sedikit legit, kasar, 2 = Lengket, kurang legit, sedikit hancur, 1 = Lengket, tidak legit, 
hancur, 4) 5 = Sangat manis, terasa anggur laut, khas dodol, $4=$ Manis, terasa anggur laut, khas dodol, 3 = Kurang manis, rasa anggur laut netral, khas dodol, $2=$ Tidak manis, sedikit ada rasa anggur laut, khas dodol berkurang, 1 = Tidak manis, rasa anggur laut tidak ada, tidak khas dodol

\section{Uji Sensori}

\section{Kenampakan}

Hasil uji sensori terhadap kenampakan pada dodol anggur laut menunjukkan nilai rerata tertinggi terdapat pada perlakuan A (AL 40 : TK $60 \%$ ) dengan nilai sebesar 4,20(utuh, kurang mengkilap, berampas, rapi, khas dodol )sedangkan nilai rerata terendah terdapat pada perlakuan C (AL 0 : TK $100 \%$ ) dengan nilai sebesar 3,43 (utuh, kurang mengkilap, tidak berampas, kurang rapi, khas dodol).Hal ini diduga karena dalam pembuatan dodol menggunakan bahan tambahan gula merah yang menyebabkan warna pada dodol menjadi kecoklatan. Hal ini didukung oleh Saroinsong et al. (2009) yang menyatakan bahwa warna dodol yang dihasilkan paling dominan adalah warna coklat yang timbul akibat penggunaan gula merah. Gula merah selain berfungsi sebagai pemanis juga sebagai pewarna coklat. Warna coklat pada dodol disebabkan karna adanya proses karamelisasi pada pengolahan gula yang digunakan pada pembuatan dodol.

\section{Aroma}

Hasil uji sensori terhadap aroma pada dodol anggur laut menunjukkan nilai rerata tertinggi terdapat pada perlakuan A (AL 40 : TK 60\%) dengan nilai sebesar 4,10(tidak ada bau anggur laut, spesifik dodol, sedikit bau tamabahan) sedangkan nilai rerata terendah terdapat pada perlakuan C (AL 0 : TK 100\%) dengan nilai sebesar 3,70(sedikit bau anggur laut, spesifik dodol berkurang, ada bau tambahan). Hal ini diduga karena pada perlakuan A (AL $40:$ TK 60\%) persentase penambahan anggur laut lebih banyak dimana anggur laut segar memiliki aroma yang cukup kuat dan dalam pembuatan dodol menggunakan bahan tambahan tepung beras ketan, sehingga dapat mempengaruhi aroma dodol yang dihasilkan. Hal ini sesuai dengan pernyataan Vitriasari dan Suyanto (2012) yang menyatakan bahwa penambahan rumput laut sangat mempengaruhi aroma dodol hal ini dikarenakan dalam pembuatan dodol tersebut banyak komponen yang tercampur seperti tepung ketan yang dapat mengurangi aroma dodol yang tidak terlalu kuat. Menurut Winarno (2002) yang menyatakan aroma pada makanan tidak hanya ditentukan oleh satu komponen tetapi oleh beberapa komponen tertentu yang menimbulkan bau yang khas dan dipengaruhi oleh perbandingan dari berbagai bahan yang digunakan.

\section{Tekstur}

Hasil uji sensori terhadap tekstur pada dodol anggur laut menunjukkan nilai rerata tertinggi terdapat pada perlakuan A (AL 40 : TK 60\%) dengan nilai sebesar 4,40(kering, legit, halus (lembut)) sedangkan nilai rerata terendah terdapat pada perlakuan C (AL 0 : TK $100 \%$ ) dengan nilai sebesar 3,90 (kurang kering, sedikit legit, kasar). Hal ini diduga karena persentase penambahan anggur laut yang lebih banyak dan penambahan tepung beras ketan lebih sedikit. Anggur laut mengandung kadar air yang cukup tinggi sehingga dapat mempengaruhi tekstur dodol yang dihasilkan menjadi legit dan kuat. Menurut Dwihandita (2009) yang menyatakan bahwa kandungan air anggur laut segar 
masih tinggi sehingga kandungan cairan dalam jaringan tubuh masih besar yang membuat tekstur anggur laut segar legit dan kuat.

\section{Rasa}

Hasil uji sensori terhadap rasa pada dodol anggur laut menunjukkan nilai rerata tertinggi terdapat pada perlakuan A (AL 40 : TK 60\%) dengan nilai sebesar 4,20(manis, terasa anggur laut, khas dodol) sedangkan nilai rerata terendah terdapat pada perlakuan C (AL 0 : TK $100 \%$ ) dengan nilai sebesar 3,70(kurang manis, rasa anggur laut netral, khas dodol). Hal ini diduga karena pada perlakuan A (AL 40 : TK $60 \%$ ) persentase penambahan anggur laut lebih banyak dibandingkan dengan perlakuan B (AL 20 : TK 80\%) dan C (AL 0 : TK 100\%). Semakin banyak konsentrasi anggur laut yang ditambahkan maka rasa khas anggur laut yang dihasilkan akan semakin terasa. Rasa dari anggur laut segar yaitu segar dan agak sedikit asin, sehingga mempengaruhi rasa produk dodolyang dibuat. Hal ini sesuai dengan penelitian Dwihandita (2009) yang menyatakan bahwa manisan anggur laut dan acar anggur memiliki rasa manis, karena penambahan larutan gula pada anggur laut memberikan perubahan rasa yang signifikan. Menurut Maghfiroh (2000), salah satu faktor yang menentukan produk diterima atau tidak oleh konsumen adalah faktor rasa. Walaupun parameter penilaian yang lain baik, jika rasanya tidak disukai maka produk akan ditolak.

\section{Uji Proksimat}

\section{Kadar Air}

Hasil uji proksimat terhadap kadar air pada dodol anggur laut menunjukkan nilai rerata tertinggi terdapat pada perlakuan A (AL $40:$ TK $60 \%$ ) dengan nilai rerata $36,12 \%$, sedangkan nilai rerata terendah terdapat pada perlakuan C (AL 0 : TK 100\%) dengan nilai rerata $23,88 \%$. Nilai kadar air dalam penelitian ini lebih tinggi dari produk variasi rasio tepung rumput laut dan tomat hasil penelitian (Lukitoet al., 2017) yaitu 23\%. Hal ini diduga karena penambahan konsentrasi anggur laut lebih banyak. Anggur laut mengandung kadar air yang tinggi sehingga dengan banyaknya penambahan anggur laut akan meningkatkan nilai kadar air pada dodol anggur laut. Hal ini sesuai dengan penelitian Dwihandita (2009) bahwa anggur laut segar memiliki rata-rata kadar air tertinggi dan lebih dari $80 \%$ diduga karena anggur laut segar tidak mengalami pengolahan lebih lanjut sehingga kandungan air dalam bahan tidak mengalami banyak perubahan. Menurut Kusumah et al. (2002), jumlah air yang ditambahkan maupun yang terkandung pada bahan penyusun berpengaruh terhadap kadar air dodol yang dihasilkan.

\section{Kadar Abu}

Hasil uji proksimat terhadap kadar abu pada dodol anggur laut menunjukkan nilai rerata tertinggi terdapat pada perlakuan A dan B (AL 40 : TK 60\%) dengan nilai rerata $0,25 \%$, sedangkan nilai rerata terendah terdapat pada perlakuan C (AL 20 : TK $80 \%$ ) dengan nilai rerata $0,23 \%$.Nilai kadar abu pada penelitian ini lebih rendah dari kadar abu produk variasi rasio tomat dan tepung rumput laut hasil penelitian (Lukitoet al., 2017) yaitu $1.69 \%$. Hal ini diduga karena kadar abu yang terkandung di dalam anggur laut yang digunakan cukup tinggi. Hal ini sesuai penelitian yang dilakukan oleh Idham (2018) bahwa kandungan kadar abu lebih tinggi diduga karena anggur laut yang digunakan mempunyai kandungan mineral yang cukup tinggi. Yani (2006), menyatakan bahwa 
rumput laut memiliki kandungan mineral yang cukup tinggi. Semakin rendah nilai kadar abu maka kandungan mineral pada bahan semakin sedikit (Panggalih, 2010). Nilai kadar abu suatu bahan pangan menunjukkan besarnya jumlah mineral yang terkandung dalam suatu bahan pangan tersebut (Apriyantono,1989).

\section{Kadar Lemak}

Hasil uji proksimat terhadap kadar lemak pada dodol anggur laut menunjukkan nilai rerata tertinggi terdapat pada perlakuan A (AL 40 : TK $60 \%$ ) dengan nilai rerata $12,41 \%$, sedangkan nilai rerata terendah terdapat pada perlakuan C (AL 0 : TK 100\%) dengan nilai rerata $10,79 \%$, kadar lemak pada penelitian ini lebih tinggi dari kadar lemak tertinggi pada produk dodol substitusi rumput laut dan kacang hijau dari hasil penelitian (Hasimet al., 2017) yaitu 7,78 \%.Hal ini diduga karena pada perlakuan A (AL 40 : TK 60\%) persentase penambahan anggur laut lebih banyak dengan persentase penambahan tepung beras ketan yang berbeda pada setiap perlakuan. Pada penelitian ini kandungan kadar lemak lebih tinggi diduga karena adanya penambahan anggur laut pada dodol. Kadar lemak anggur laut segar menurut (Santoso et al., 2006) yaitu $0,5 \%$, selain itu adanya penambahan tepung beras ketan yang memiliki kandungan lemak sebanyak $0,7 \%$ yang menyebabkan kadar lemak pada dodol menjadi tinggi (Aan, 2007).

\section{Kadar Protein}

Hasil uji proksimat terhadap kadar air pada dodol anggur laut menunjukkan nilai rerata tertinggi terdapat pada perlakuan A (AL 40 : TK $60 \%$ ) dengan nilai rerata $16,61 \%$, sedangkan nilai rerata terendah terdapat pada perlakuan C (AL 0 : TK 100\%) dengan nilai rerata $13,18 \%$. Nilai kadar protein pada penelitian ini lebih tinggi dari kadar protein tertinggi pada produk dodol substitusi rumput laut dengan kacang hijau dari hasil penelitian (Hasimet al., 2017) yaitu 12,21\%. Hal ini diduga karena tepung beras ketan sebagai bahan tambahan pada dodol anggur laut memiliki kandungan protein yang cukup tinggi yaitu 79,4\% (Aan, 2007), selain itu penambahan anggur laut mampu meningkatkan kadar protein dodol. Menurut Verlaque et al. (2003) yang menyatakan bahwa kadar protein yang terkandung pada anggur laut yaitu 2,7\%. Menurut Lukito et al. (2017) yang menyatakan bahwa semakin banyak penambahan rumput laut pada pembuatan dodol maka akan menghasilkan kadar protein yang lebih tinggi.

\section{Kadar Karbohidrat}

Hasil uji proksimat terhadap kadar karbohidrat pada dodol anggur laut menunjukkan nilai rerata tertinggi terdapat pada perlakuan A (AL 40 : TK $60 \%$ ) dengan nilai rerata 50,36\%, sedangkan nilai rerata terendah terdapat pada perlakuan C (AL 0 : TK 100\%) dengan nilai rerata $34,57 \%$. Nilai kadar karbohidrat dalam penelitian ini lebih rendah dari kadar karbohidrat pada produk substitusi tomat dan tepung rumput laut hasil penelitian (Lukitoet al., 2017) yaitu 57,74\%. Hal ini diduga karena persentase penambahan anggur laut yang lebih banyak dan adanya penambahan tepung beras ketan sehingga dapat meningkatkan kadar karbohidrat. Hal ini sesuai dengan pendapat Verlaque et al. (2003) yang menyatakan bahwa kadar karbohidrat yang terkandung dalam anggur laut segar yaitu sebanyak $8,47 \%$. Adanya penambahan tepung beras ketan pada pembuatan dodol mampu meningkatkan 
kadar karbohidrat. Hal ini sesuai dengan pendapat Suyanti dan Sunarmani (2004) bahwa tepung ketan mengandung karbohidrat yang cukup tinggi, karbohidrat di dalam tepung ketan terdapat dua senyawa yaitu amilosa dan amilopektin. Semakin banyak konsentrasi tepung ketan yang digunakan maka fraksi amilopektinnya semakin tinggi. Aan (2007), menambahkan bahwa kadar karbohidrat yang terkandung di dalam tepung beras ketan yaitu $79,4 \%$.

\section{Uji Antioksidan}

\section{Aktivitas Antioksidan}

Hasil uji aktivitas antioksidan pada dodol anggur laut dengan menunjukkan nilai $\mathrm{IC}_{50}$ rerata tertinggi terdapat pada perlakuan A (AL 40 : TK $60 \%$ ) dengan nilai rerata 619,206 $\mu \mathrm{g} / \mathrm{mL}$, sedangkan nilai rerata terrendah terdapat pada perlakuan C (AL 0 : TK $100 \%$ ) dengan nilai rerata 853,029 $\mu \mathrm{g} / \mathrm{mL}$. Hal ini diduga karena pada perlakuan A persentase penambahan anggur laut lebih banyak dimana anggur laut sebagai sumber antioksidan, tetapi adanya proses pengolahan dodol yang menggunakan proses pemasakan maka aktivitas antioksidan yang terdapat pada anggur laut menjadi rendah. Menurut Apriyantono dalam Dwihandita (2009) yang menyatakan bahwa senyawa antioksidan sangat mudah mengalami perubahan. Hal ini dikarenakan berbagai jenis pengolahan dapat mengakibatkan hilangnya senyawa antioksidan yang terdapat dalam suatu bahan. Proses penanganan, pemasakan maupun penambahan bahan tambahan pada produk pangan diduga dapat menghilangkan beberapa senyawa bioaktif yang terkandung didalam anggur laut. Beberapa proses penanganan prakonsumsi seperti pengeringan, proses pemasakan, pembuatan manisan, dan pembuatan acar mampu menurunkan aktivitas antioksidan C.racemosa (Dwihandita, 2009). Berdasarkan hasil penelitian, anggur lauttermasuk organisme yang mempunyai aktivitas antioksidan yang lemah dengan rerata nilai $\mathrm{IC}_{50}$ yaitu $<150$ (Aryanto, 2006).

Beberapa penelitian juga memperoleh simpulan hasil yang berbeda yaitumemiliki kandungan antioksidan yang sangat lemah. Aryudhani (2007)menemukan nilai IC50 dari C. racemosa sebesar 1394,88 ppm, Dwihandita (2009)1115,94 ppm dan Vinayak et al., (2011) 1473 ppm. Akan tetapi, Chia et al.,(2015) yang mengambil $C$. racemosa dari perairan Malaysia memeroleh nilai IC50yang lebih rendah $(90 \mathrm{ppm})$ yang berarti $C$. racemosa memiliki aktivitasantioksidan yang tinggi (Erwin, 2013). Hal itu didukung oleh Fithriani (2009)membuktikan bahwa perbedaan nilai IC50 yang dinyatakan sebagai aktivitasantioksidan juga dapat dipengaruhi oleh treatment atau penanganan dari bahanbaku yang akan diuji.

\section{KESIMPULAN}

Berdasarkan hasil dan pembahasan, maka dapat disimpulkan sebagai berikut :

1. Perbandingan jumlah anggur laut dan tepung beras ketan pada nilai sensori berpengaruh nyata terhadap kenampakan, tekstur dan rasa pada dodol, tetapi berpengaruh tidak nyata pada aroma dodol. Nilai sensori terbaik terdapat pada perbandingan AL 40: TK 60\%.

2. Perbandingan jumlah anggur laut dan tepung beras ketan pada nilai proksimat berpengaruh nyata terhadap kadar air, kadar protein, dan kadar karbohidrat, tetapi berpengaruh tidak nyata terhadap kadar abu dan 
kadar lemak. Nilai proksimat terbaik terdapat pada perbandingan AL 40: TK $60 \%$.

3. Perbandingan jumlah anggur dan tepung beras ketan pada uji antioksidan berpengaruh tidak nyata. Nilai rerata tertinggi aktivitas antioksidan terdapat pada perbandingan AL 40 : TK 60\% dengan nilai $\mathrm{IC}_{50}$ yaitu 619,206 $\mu \mathrm{g} / \mathrm{mL}$.

\section{DAFTAR PUSTAKA}

Aan MH. 2007. Pengaruh Total Mikroba pada Merk Ragi dan Lama Fermentasi terhadap Kadar Alkohol Tape Ketan Putih (Oryza sativa l. var. Forma glutinosa), Malang: Fakultas Sains dan Teknologi, Universitas Negeri Malang.

Anwar LO. Bubun RL, Rosmawati. 2016. Manfaat Anggur Laut (Caulerpa racemosa) dan Penanganannya dengan Melibatkan Masyarakat Pantai di Desa Rumba-Rumba. Seminar Nasional dan Gelar Produk.

AOAC. 2005. Officiall Methods of Analysis. 18th ed.Association of Offical Analytical Chemists, Washington DC.

Apriyantono DFA. 1989. Petunjuk Laboratorium Analisis Pangan.Departemen Pendidikan dan Kebudayaan Direktorat Jenderal Pendidikan Tinggi Pusat Antar Universitas Pangan dan Gizi IPB. Bogor.

Aryanto R. 2006. Uji Aktivitas Antioksidan , Penentuan Kandungan Fenolik dan Flavonoid Total Fraksi Kloroform dan Fraksi Air Ekstrak Metanolik. Pegagan.
Fakultas Farmasi Universitas Gajah Mada.

Aryudhani N. 2007. Kandungan Senyawa Fenol Rumput Laut Caulerpa racemosa dan Aktivitas Antioksidannya. Bogor: Program Studi TeknologiHasil Perikanan. Fakultas Perikanan dan Ilmu Kelautan. Institut PertanianBogor.

Astawan, Wahyuni. 1991. Teknologi Pengolahan Pangan Nabati Tepat Guna. Dalam Irawati, R. 2001. Pembuatan Dodol waluh (Kajian PenambahanTepung Ketan dan Terigu Serta Gula Pasir) Terhadap Sifat Fisik, Kimia,dan Organoleptik. [Skripsi]. Fakultas Teknologi Pertanian Universitas Brawijaya, Malang.

Chew YL, Lim YY, Omar M, Khoo KS. 2007. Antioxidant Activity of three Edible Seaweeds from two areas in South East Asia. Food Science and Technology. 41: 1067-1072.

2008. Antioxidant Activity of three Edible Seaweeds from two areas in South East Asia. Food Science and Technology. 41 : 1067-1072.

Chia YY, Kanthimathi MS, Khoo KS, Rajarajeswaran J, Cheng HM, Yap WS. 2015. Antioxidant and Cytotoxic Activities of Three Species ofTropical Seaweeds. BMC Complementary and Alternative Medicine15:339.

Dwihandita N. 2009. Perubahan Kandungan Antioksidan Anggur Laut (Caulerpa. racemosa) Akibat Pengolahan[Skripsi]. 
Fakultas Perikanan dan Ilmu Kelautan Institut Pertanian Bogor, Bogor. 97 hal.

Erwin, Sari, FD, Saleh C. 2013. Uji Toksisitas dan Penentuan AktivitasAntioksidan dengan Metode DPPH dari Metabolit sekunder Fraksi n-Heksana, Etil Asetat dan Methanol-Air Daun Sisik Naga (Drymoglossumpiloselloides

[linn]. Pr.). Prosiding Seminar Nasional Kimia 2013, ISBN:978-602-19421-0-9.

Fithriani D. 2009. Potensi Antioksidan Caulerpa racemosa di Perairan Teluk Harun Lampung [Thesis]. Program Pasca sarjana. Institut Pertanian Bogor.

Haryadi. 2006. Teknologi Pengolahan Beras. Universitas Gadjah Mada Press. Yogyakarta. 239 hlm.

Hasim L, Asyik N dan Hermanto. 2017. Kajian Substitusi Rumput Laut (Euchuma cottoni) dan Kacang Hijau (Phaseolus eureus) dalam Pembuatan Dodol terhadap Sifat Organoleptik dan Nilai gizi. Prosiding Seminar Nasional FKPT-TPI. Fakultas Teknologi dan Industri Pertanian. Universitas Halu Oleo.

Idham NP, Isamu KT, Suwarjoyowirayatno. 2018. Analisis Organoleptik, dan Kandungan Kimia Permen Jelly Anggur Laut (Caulerpa racemosa). Jurnal Fish Protech. 1(2):95-101.

Kusumah FC, Maheswari RRA, Wulandari Z. 2002. Standarisasi Suhu Pemanasan Pada Proses Pengolahan Dodol Susu. Med Perternakan. 25:75-83.
Lukito MS, Giyarto, Jayus. 2017. Sifat Fisik, Kimia Dan Organoleptik Dodol Hasil Variasi Rasio Tomat Dan Tepung Rumput Laut. Junal Agroteknologi. 11(1).

Maghfiroh, I. 2000. Pengaruh Penambahan Bahan Pengikat terhadap Karakteristik Nugget Ikan Patin (Pangasius pangasius). [Skripsi]. Fakultas Perikanan dan Ilmu Kelautan. Program Studi Teknologi Hasil Perikanan, Institut Pertanian Bogor.

Panggalih AI. 2010. Pengaruh jenis Kemasan dan Suhu Penyimpanan Pada Umur Simpan Teh Hijau. [Skripsi]. Bogor: Institut Pertanian Bogor.

Santoso JS, Gunji Y, Yoshie, Suzuki T. 2006. Mineral contents of Indonesian seaweeds and mineral solubility affected by basic cooking. Food Science Tec. 12(1): 59-66.

Saroinsong, R.M., Mandey, L dan Lalujan, L. 2009. Pengaruh Penambahan Labu Kuning (Curcubita moschata) terhadap Kualitas Fisikokimia Dodol. Universitas Sam Ratulangi, Manado. 6 (15) : 1-8.

Setyaningsih D, Apriyantono A, Sari MP. 2010. Analisis Sensori untuk Industri Pangan dan Agro. Bogor (ID): IPB Press.

Steel RGD dan Torrie JH. 1993. Prinsip dan Prosedur Statistika. Jakarta: Penerbit PT. Gramedia Pustaka Utama.

Sudjana. 2000. Metode Statistika. Bandung : PT. Gramedia Pustaka Utama. 
Suprapto H. 2006. Pengaruh Substitusi Tapioka untuk Tepung Beras Ketan terhadap Perbaikan Kualitas Wingko. Jurnal Teknologi Pertanian 2(1) : 19 23.

Suyanti S, Sunarmani. 2004. Membuat Aneka Dodol Buah. Penebar Swadaya, Jakarta.

Tristantini D, Ismawati A, Pradana BT, Gabriel J. 2016. Pengujian Aktivitas Antioksidan Menggunakan Metode DPPH pada Daun Tanjung (Mimusops elengi L). Prosiding Seminar Nasional Teknik Kimia "Kejuangan" Pengembangan Teknologi Kimia untuk Pengolahan Sumber Daya Alam Indonesia.

Triwitono, P. 2012. Beras dan Sifat Fisika-Kimianya (online).www.alatcetakrenggina ng.com. Diakses pada hari senin 30 Mei 2018.

Turangan FAC. 2000. Pertumbuhan, Variasi Intraspesifik, Biomassa Total dan Kandungan Nutrisi Alga Hijau Calerpa racemosa (Forsskal) J. Agardh di perairan tongkaine, kota Manado Sulawesi Utara.

Verlaque M, Durand C, Huisman JM, Bouduresque, CF, Le Parco Y. 2003. On Identity andOrigin of TheMediterranen Invasive $C$. racemosa. European Journal of Physocology.

Vinayak RC, Sudha SA, Chatterji A. 2011. Bio-screening of a Few GreenSeaweeds from India for their Cytotoxic and Antioxidant Potential. J. SciFood Agric.
Vitriasari E, Suyanto A. 2012. Karakteristik Dodol Ubi Jalar Ungu (Ipoma batatas blackie) dengan Variasi Penamabahan Tepung Rumput Laut. Jurnal Pangan dan Gizi. 03(06).

Winarno FG . 2002. Teknologi Pengolahan Gula Pasir. Pustaka Gramedia. Jakarta.

Yani HI. 2006. Karakteristik Fisika Kimia Permen Jelly dari Rumput Laut Eucheuma spinosum dan Eucheuma cottonii.[Skripsi]. Bogor: InstitutPertanian Bogor. 